\title{
Characterization of $\mathbf{P} 2 \mathrm{X}_{7}$ Purinergic Receptors and Their Function in Rat Lacrimal Gland
}

\author{
Robin R. Hodges, Joanna Vrouvlianis, Marie A. Shatos, and Darlene A. Dartt \\ From the Schepens Eye Research Institute, Department of Ophthalmology, Harvard Medical \\ School, Boston, Massachusetts
}

\section{Abstract}

PURPOSE-To characterize the effects of $\mathrm{P}_{2} \mathrm{X}_{7}$ purinergic receptors on lacrimal gland function.

METHODS- $\mathrm{P}_{2} \mathrm{X}_{7}$ purinergic receptors were identified by RT-PCR, Western blot analysis, and immunofluorescence techniques. Rat lacrimal gland acini were isolated by collagenase digestion. Acini were incubated with the fluorescent indicator molecule fura 2 , and $\left[\mathrm{Ca}^{2+}\right]_{i}$ was measured by a fluorescence imaging system. Protein secretion was measured with a fluorescence assay system. Activation of ERK 1/2 was determined by Western blot analysis with an antibody against phosphorylated (active) ERK 1/2.

RESULTS-P2X 7 receptors were present in the lacrimal gland by RT-PCR and Western blot analysis. These receptors were located in the membranes of acinar and ductal cells and the cytoplasm of acinar cells. Activation of $\mathrm{P} 2 \mathrm{X}_{7}$ receptors with (benzoylbenzoyl)adenosine 5 '-triphosphate increased $\left[\mathrm{Ca}^{2+}\right]_{\mathrm{i}}$, peroxidase secretion, and ERK $1 / 2$ activation, each of which was inhibited by the $\mathrm{P}_{2} \mathrm{X}_{7}$ receptor inhibitors Brilliant Blue G or A 438079.

CONCLUSIONS $-\mathrm{P} 2 \mathrm{X}_{7}$ purinergic receptors are present in rat lacrimal gland and when stimulated increase $\left[\mathrm{Ca}^{2+}\right]_{i}$, protein secretion, and ERK $1 / 2$ activation.

The lacrimal gland is a tubuloacinar exocrine gland that is responsible for secretion of the aqueous portion of the tear film. ${ }^{1}$ The aqueous portion consists of water, proteins, and electrolytes. Regulation of secretion is under neural control. Activation of the sensory nerves in the cornea and conjunctiva initiates an afferent pathway leading to the central nervous system. This, in turn, activates an efferent pathway to stimulate parasympathetic and sympathetic nerves that innervate the lacrimal gland. ${ }^{1}$

The functional unit of the lacrimal gland is the acinus structure, which consists of polarized cells connected around a central lumen via tight junctions. Receptors for neurotransmitters are present on the basolateral membranes. When these receptors are stimulated, they activate signal transduction pathways to stimulate protein secretion across the apical membrane and into small ducts. ${ }^{1}$ Epithelial cells line the ducts and modify the primary fluid. The small ducts coalesce to larger ducts and eventually into the main excretory duct, which empties onto the ocular surface. In addition to acinar and ductal cells, the third major cell type in the lacrimal gland is myoepithelial cells. These are large stellate-shaped cells that surround the acini and are believed to contract to help expel secretory products from the acinar cells, as occurs in the mammary gland.

Copyright $\odot$ Association for Research in Vision and Ophthalmology

Corresponding author: Robin R. Hodges, Schepens Eye Research Institute, Department of Ophthalmology, Harvard Medical School, 20 Staniford Street, Boston, MA 02114; robin.hodges@ schepens.harvard.edu.

Disclosure: R.R. Hodges, None; J. Vrouvlianis, None; M.A. Shatos, None; D.A. Dartt, None 
We have previously identified several major pathways activated by nerves that cause protein secretion. Parasympathetic and sympathetic nerves are major stimuli of protein secretion. Acetylcholine, released from parasympathetic nerves, binds to the $\mathrm{M}_{3}$ muscarinic receptor to initiate secretion via the hydrolysis of phosphoinositol bisphosphate into 1,4,5 inositol trisphosphate $\left(\mathrm{IP}_{3}\right) / \mathrm{Ca}^{2+}$ and diacylglycerol (DAG)/protein kinase $\mathrm{C}(\mathrm{PKC})$ pathways. ${ }^{2-} 4$

In addition to stimulating protein secretion, cholinergic agonists also activate another pathway which attenuates protein secretion, namely the extracellular signal-related kinase 1/2 (ERK $1 / 2$, otherwise known as p42/p44 mitogen-activated protein kinase [MAPK]) pathway. Cholinergic agonists activate this pathway through the stimulation of nonreceptor tyrosine kinases Pyk2 and cSrc. This initiates the Ras/Raf/MEK kinase pathway, which culminates in the activation of ERK $1 / 2 .{ }^{5,} 6$

Sympathetic nerves release the neurotransmitter norepinephrine to activate $\alpha_{1 \mathrm{D}}$-adrenergic receptors. These receptors stimulate endothelial nitric oxide synthase to activate guany-late cyclase, which increases the intracellular concentrations of cGMP. cGMP leads to the stimulation of protein secretion. In addition, these receptors transactivate the EGF receptor to induce the ERK1/2 signaling cascade, which attenuates secretion. ${ }^{7}$

Purinergic receptors are identified by their ability to bind purines. This class of receptors has been divided into two major types, $\mathrm{P} 1$ and $\mathrm{P} 2$. P1 receptors are classic $\mathrm{G}$ protein-coupled receptors (GPCRs). P2 receptors are further subdivided into two groups, P2X and P2Y. P2X receptors are ATP-gated nonselective ion-gated channels, whereas P2Y receptors are GPCRs. ${ }^{8}$ Seven $\mathrm{P} 2 \mathrm{X}$ receptors $\left(\mathrm{P} 2 \mathrm{X}_{1}-\mathrm{P} 2 \mathrm{X}_{7}\right)$ and at least $12 \mathrm{P} 2 \mathrm{Y}$ receptors have been cloned to date.

P2X receptors are closely related receptors containing two transmembrane regions with a large extracellular domain with multiple glycosylation sites. $\mathrm{P} 2 \mathrm{X}_{7}$ receptors have a larger intracellular domain than $\mathrm{P} 2 \mathrm{X}_{1-6}$, and though $\mathrm{P} 2 \mathrm{X}_{1-6}$ can be activated by low concentrations of ATP $\left(\mathrm{EC}_{50} 1-10 \mu \mathrm{M}\right), \mathrm{P} \mathrm{X}_{7}$ receptors require much higher concentrations of ATP to be activated $\left(\mathrm{EC}_{50} 300 \mu \mathrm{M}\right) .{ }^{9}$ In addition, $\mathrm{P} 2 \mathrm{X}_{7}$ receptors have a unique characteristic that aids in identification of this receptor in tissues. First, the response of $\mathrm{P} 2 \mathrm{X}_{7}$ receptors is enhanced in the absence of $\mathrm{Mg}^{2+}$. In macrophages and microglia, prolonged $\mathrm{P} 2 \mathrm{X}_{7}$ agonist application can also lead to membrane blebbing and microvesiculation that is accompanied by IL- $1 \beta$ secretion and could contribute to an inflammatory response. ${ }^{10,11}$ In many cases, prolonged activation of $\mathrm{P}_{2} \mathrm{X}_{7}$ receptors and pores leads to cell death by necrosis or apoptosis.

We hypothesize that $\mathrm{P} 2 \mathrm{X}_{7}$ receptor stimulation plays a significant role in the normal function of the lacrimal gland. To test this hypothesis, we sought to determine whether $\mathrm{P} 2 \mathrm{X}_{7}$ receptors are present in the rat lacrimal gland, whether activation of $\mathrm{P} 2 \mathrm{X}_{7}$ receptors plays a role in protein secretion, and whether activation of $\mathrm{P} 2 \mathrm{X}_{7}$ receptors increases $\left[\mathrm{Ca}^{2+}\right]_{\mathrm{i}}$.

\section{MATERIALS AND METHODS}

\section{Materials}

$\mathrm{P} 2 \mathrm{X}_{7}$ rabbit polyclonal antibody and the control peptide were purchased from Alomone Laboratories (Jerusalem, Israel). Monoclonal antibodies directed against ERK 1/2 phosphorylated on Tyr202/204 (activated ERK), total ERK2, and mouse secondary antibody conjugated to horseradish peroxidase (HRP) were from Santa Cruz Biotechnology (Santa Cruz, CA). Rabbit secondary antibody conjugated to HRP was purchased from Millipore (Billerica, MA), whereas mouse secondary antibody conjugated to Cy2 was from Vector Laboratories (Burlingame, CA). Phalloidin conjugated to rhodamine was purchased from Sigma Chemical (St. Louis, MO). 3-\{[5-(2,3-Dichlorophenyl)-1H-tetrazol-1-yl]methyl $\}$ pyridine hydrochloride (A 438079) was from Tocis Bioscience (Ellisville, MO). Fura-2 AM and reagents (Amplex 
red, TRIzol) were from Invitrogen (Carlsbad, CA). Reverse transcription system and PCR products were purchased from Promega (Madison, WI). Primers to G3DPH were purchased from Clonetics (Mountain View, CA). Collagenase (CLSIII) was purchased from Worthington Biochemicals (Lakewood, NJ). All other reagents were from Sigma Chemical.

\section{Animals}

All experiments were conducted in accordance with the ARVO Statement for the Use of Animals in Ophthalmic and Vision Research and were approved by the Schepens Eye Research Institute Animal Care and Use Committee. Male Sprague-Dawley rats (125-150 g) were purchased from Taconic Farms (Germantown, NY). They were maintained in constanttemperature rooms with fixed light-dark intervals of 12 hours and were fed ad libitum. The rats were anesthetized for 1 minute in $\mathrm{CO}_{2}$ and decapitated. Both exorbital lacrimal glands were removed.

\section{RT-PCR}

The lacrimal gland was removed and homogenized in reagent (TRIzol; Invitrogen), and total RNA was isolated according to the manufacturer's instructions. RNA was also isolated from rat brain to use as a positive control because $\mathrm{P} 2 \mathrm{X}_{7}$ receptors are known to be present in this tissue. ${ }^{12}$ One microgram of purified total RNA was used for complementary DNA (cDNA) synthesis using the reverse transcription system. cDNA was amplified by the polymerase chain reaction (PCR) using primers specific to either $\mathrm{P}_{2} \mathrm{X}_{7}$ receptors or G3DPH in a thermal cycler (PCR Sprint; ThermoHybaid, Ashton, UK). The primers used for $\mathrm{P}_{2} \mathrm{X}_{7}$ were derived from previously published sequences ${ }^{13}$ (antisense, GTGCCATTCTGACCAGGGTTGTATAAA; sense, GCCACCTCTGTAAAGTTCTCTCCGAT).

The PCR reaction consisted of $0.5 \mu \mathrm{M}$ sense and antisense primers, $200 \mu \mathrm{M}$ each dNTP, 1.5 $\mu \mathrm{M} \mathrm{MgCl}_{2}, 1.25 \mathrm{U} \mathrm{Taq}$ polymerase, and $1 \mu \mathrm{L}$ cDNA. The cycling conditions were 5 minutes hot start at $94^{\circ} \mathrm{C}, 40$ cycles of denaturation for 1 minute at $94^{\circ} \mathrm{C}$, annealing for 1 minute at $59^{\circ}$ $\mathrm{C}$, and extension for 1 minute at $72^{\circ} \mathrm{C}$ and a final extension at $72^{\circ} \mathrm{C}$ for 5 minutes. Samples with no cDNA served as the negative controls, whereas the presence of RNA for the housekeeping gene $G 3 D P H$ was used as a positive control. After amplification, the products were separated by electrophoresis on a $1.5 \%$ agarose gel and visualized by ethidium bromide staining.

\section{Western Blot Analysis}

The presence of the $\mathrm{P} 2 \mathrm{X}_{7}$ receptor in lacrimal gland was determined by Western blot analysis. The gland was homogenized in RIPA buffer containing $10 \mathrm{mM}$ Tris- $\mathrm{HCl}(\mathrm{pH} 7.4), 150 \mathrm{mM}$ $\mathrm{NaCl}, 1 \%$ deoxycholic acid, $1 \%$ Triton $\mathrm{X}-100,0.1 \%$ SDS, and 1 mM EDTA containing protease inhibitors (phenylmethylsulfonyl fluoride $100 \mu \mathrm{L} / \mathrm{mL}$, aprotinin $30 \mu \mathrm{L} / \mathrm{mL}$ ) and 100 $\mathrm{nM}$ sodium orthovanadate. Homogenized cells were sonicated and centrifuged at $2000 \mathrm{~g}$ for 15 minutes at $4{ }^{\circ} \mathrm{C}$. Proteins in the supernatant were separated by sodium dodecyl sulfatepolyacrylamide gel electrophoresis on a $10 \%$ gel and transferred to nitrocellulose membranes. Nitrocellulose membranes were blocked overnight at $4{ }^{\circ} \mathrm{C}$ in $5 \%$ nonfat dried milk in buffer containing $10 \mathrm{mM}$ Tris- $\mathrm{HCl}(\mathrm{pH} 8.0), 150 \mathrm{mM} \mathrm{NaCl}$, and $0.05 \%$ Tween-20 and then were incubated with the $\mathrm{P} 2 \mathrm{X}_{7}$ antibody (1:300 dilution) for 1 hour at room temperature or overnight at $4{ }^{\circ} \mathrm{C}$, followed by incubation with HRP-conjugated secondary antibody (1:5000 dilution). For preabsorption control, the $\mathrm{P}_{2} \mathrm{X}_{7}$ antibody was preincubated with the control peptide at 1:10 fold excess overnight before it was applied to the Western blot overnight and incubation with the secondary antibody. 


\section{Immunohistochemistry}

Lacrimal glands were fixed in $4 \%$ formaldehyde diluted in phosphate-buffered saline (PBS; $145 \mathrm{mM} \mathrm{NaCl}, 7.3 \mathrm{mM} \mathrm{Na}_{2} \mathrm{HPO}_{4}$, and $2.7 \mathrm{mM} \mathrm{NaH}_{2} \mathrm{PO}_{4}$ [pH 7.2]) for 4 hours at $4^{\circ} \mathrm{C}$. The tissue was then preserved in $30 \%$ sucrose in PBS at $4^{\circ} \mathrm{C}$ overnight, followed by embedding in optimal cutting temperature compound. Six-micron sections were cut, placed on slides, and air dried for 2 hours. The sections were rinsed for 5 minutes in PBS, and nonspecific sites were blocked by incubation with $10 \%$ normal goat serum, $1 \%$ bovine serum albumin, and $0.2 \%$ Triton X-100 in PBS for 45 minutes at room temperature. Sections were then incubated with the $\mathrm{P}_{2} \mathrm{X}_{7}$ primary antibody (1:200 dilution) for 2 hours at room temperature in a humidified chamber. The secondary antibody conjugated to Cy2 (1:150 dilution) was applied for 1 hour at room temperature. Phalloidin conjugated to rhodamine was used at 1:1000 dilution and added with the Cy2 secondary antibody. Cover-slips were mounted with a medium consisting of glycerol and para-phenylenediamine. Preabsorption control was performed by incubating the $\mathrm{P} 2 \mathrm{X}_{7}$ antibody with a 10 -fold excess of the control peptide at $4^{\circ} \mathrm{C}$ overnight before the solution was applied to the lacrimal gland section for 2 hours at room temperature. Sections incubated in the absence of primary antibody also served as a negative control. The sections were viewed by microscopy (Eclipse E80i; Nikon, Tokyo, Japan), and micrographs were taken with a digital camera (Spot; Diagnostic Instruments, Inc., Sterling Heights, MI).

\section{Preparation of Lacrimal Gland Acini}

Acini were prepared by collagenase digestion. In brief, lacrimal glands were trimmed and fragmented before incubation with collagenase CLSIII $(100 \mathrm{U} / \mathrm{mL})$ in Krebs-Ringer bicarbonate (KRB) buffer (119 mM NaCl, $4.8 \mathrm{mM} \mathrm{KCl}, 1 \mathrm{mM} \mathrm{CaCl}_{2}, 1.2 \mathrm{mM} \mathrm{MgSO}_{4}, 1.2$ $\mathrm{mM} \mathrm{KH} \mathrm{PO}_{4}, 25 \mathrm{mM} \mathrm{NaHCO}_{3}, 10 \mathrm{mM}$ HEPES, and $5.5 \mathrm{mM}$ glucose [pH 7.45]) and $0.5 \%$ $\mathrm{BSA}$ at $37^{\circ} \mathrm{C}$. Fragments were subjected to pipetting through tips of decreasing diameter, filtered through nylon mesh (150- $\mu \mathrm{m}$ pore size), and centrifuged briefly (50 $g, 2$ minutes). The pellet was washed twice through a $4 \%$ BSA solution in KRB buffer. The dispersed acini were allowed to recover for 60 minutes at $37^{\circ} \mathrm{C}$ before use.

\section{Measurement of $\left[\mathrm{Ca}^{2+}\right]_{i}$}

Acini were incubated for 30 minutes at room temperature in the dark with KRB-HEPES containing $0.5 \%$ BSA, $0.5 \mu \mathrm{M}$ fura 2 tetra-acetoxymethyl ester, $8 \mu \mathrm{M}$ pluronic acid F127, and $250 \mu \mathrm{M}$ sulfinpyrazone. The cells were washed in KRB buffer containing $250 \mu \mathrm{M}$ sulfinpyrazone. Calcium measurements were obtained with a ratio imaging system (InCyt Im2; Intracellular Imaging, Cincinnati, OH) using excitation wavelengths of 340 and $380 \mathrm{~nm}$ and an emission wavelength of $505 \mathrm{~nm}$. At least 10 acini clumps were selected for each condition. The experiments were then repeated for cells from at least three animals. 2'(3')-O-(4Benzoylbenzoyl)adenosine 5'-triphosphate (BzATP), a P2X 7 receptor agonist, or the muscarinic receptor agonist carbachol (Cch), the positive control, was added, and data were collected in real time. Data are presented as either the actual $\left[\mathrm{Ca}^{2+}\right]_{\mathrm{i}}$ with time or as change in peak calcium concentrations. Change in peak calcium concentrations were calculated by subtracting the average of the basal values (before the addition of agonist) from the peak calcium value. Inhibitors were added 20 minutes before agonists were added.

\section{Measurement of Peroxidase Secretion}

After the recovery period, acini were incubated in KRB buffer containing 0.5\% BSA for 40 minutes at $37^{\circ} \mathrm{C}$ in the presence of BzATP or Cch. Inhibitors were added 20 minutes before BzATP. After a brief centrifugation, the supernatant was collected and the pellet was homogenized in $10 \mathrm{mM}$ Tris $\mathrm{HCl}, \mathrm{pH}$ 7.5. Peroxidase activity, an index of protein secretion, was measured in duplicate in both the supernatant and the pellet. Peroxidase was measured using a reagent (Amplex Red; Invitrogen), which, when oxidized by peroxidase in the presence 
of hydrogen peroxide, produces a highly fluorescent molecule. The amount of fluorescence in the supernatant and pellet was quantified on a fluorescence microplate reader (model FL600; Bio-Tek, Winooski, VT) with an excitation wavelength of $530 \mathrm{~nm}$ and an emission wavelength of $590 \mathrm{~nm}$. Peroxidase was expressed as a percentage of peroxidase secreted into the media (supernatant) compared with total peroxidase present in the cells (pellet + supernatant). Data are expressed as fold increase $\times$ basal, which was set as 1 .

\section{Measurement of ERK 1/2 Activity}

Activation of ERK 1/2 was measured by Western blot analysis. Acini were incubated with BzATP or Cch for 10 minutes in KRB buffer. Inhibitors were added 20 minutes before BzATP. Reaction was terminated by brief centrifugation. The pellet was resuspended in RIPA buffer and analyzed by Western blot on a 10\% polyacrylamide gel, as described, using an antibody for total ERK (ERK2, 1:1000) or phosphorylated (activated) ERK 1 and 2 (1:500 dilution) overnight at $4{ }^{\circ} \mathrm{C}$. The secondary antibody (1:2000) was added for 30 minutes at room temperature. Films were scanned, and data were analyzed using ImageJ software (developed by Wayne Rasband, National Institutes of Health, Bethesda, MD; available at http://rsb.info.nih.gov/ij/index.html). Values for phosphorylated enzymes (amounts for ERK 1 and 2 were scanned together) were normalized to the amount of total enzyme using antibodies to nonphosphorylated enzyme, and were expressed as fold times basal, which was set as 1 . This is described previously. ${ }^{5,6}, 14$

\section{Data Presentation and Statistical Analysis}

Data are expressed as the fold increase over the basal value, which was standardized to 1.0. Results are expressed as the mean \pm SEM. Data were analyzed by Student's $t$-test. $P<0.05$ was considered statistically significant.

\section{RESULTS}

\section{Identification of $\mathrm{P}_{2} \mathrm{X}_{\mathbf{7}}$ Receptors in the Lacrimal Gland}

To determine whether $\mathrm{P} 2 \mathrm{X}_{7}$ receptors are present in the rat lacrimal gland, RT-PCR was performed on RNA isolated from rat lacrimal gland with primers specific to $\mathrm{P} 2 \mathrm{X}_{7}$ and the housekeeping gene G3DPH. As shown in Figure 1A, a PCR product at the expected size of $354 \mathrm{bp}$ for $\mathrm{P}_{2 \mathrm{X}_{7}}$ receptor and a band of $452 \mathrm{bp}$ for G3DPH were present in both brain and lacrimal gland.

To ensure that the $\mathrm{P} 2 \mathrm{X}_{7}$ protein is expressed in the lacrimal gland, proteins in lysates from brain and lacrimal gland were separated by electrophoresis and subjected to Western blot analysis using an antibody specific to $\mathrm{P} 2 \mathrm{X}_{7}$ receptors. Both the brain and the lacrimal gland contained proteins at $69 \mathrm{kDa}$, the calculated molecular weight of the $\mathrm{P}_{2} \mathrm{X}_{7}$ receptor (Fig. 1B). Incubation of the primary antibody with the control peptide eliminated the bands in both brain and lacrimal gland (Fig. 1B).

The location of $\mathrm{P} 2 \mathrm{X}_{7}$ receptors in the lacrimal gland was then determined. Lacrimal gland sections were incubated with the same $\mathrm{P} 2 \mathrm{X}_{7}$ receptor antibody used for Western blot experiments (Fig. 2A) and phalloidin conjugated to rhodamine, which binds to actin (Fig. 2B). $\mathrm{P}_{2} \mathrm{X}_{7}$ receptors were present at or near the apical and basolateral membranes of virtually all acinar cells and ductal cells, similar to the location of actin (Fig. 2C; $\mathrm{P} 2 \mathrm{X}_{7}$ shown in green, phalloidin shown in red). In addition, $\mathrm{P} 2 \mathrm{X}_{7}$ receptors were also present in the cytosol of acinar cells. Incubation with the peptide to which the $\mathrm{P}_{2} \mathrm{X}_{7}$ antibody was generated abolished the staining (Fig. 2D). These experiments demonstrate that $\mathrm{P} 2 \mathrm{X}_{7}$ receptors are present in rat lacrimal gland. 


\section{Effect of Activation of $\mathrm{P} 2 \mathrm{X}_{7}$ Receptors on Intracellular $\left[\mathrm{Ca}^{2+}\right]$}

Given that $\mathrm{P} 2 \mathrm{X}$ receptors are nonselective ion channels, measurement of $\left[\mathrm{Ca}^{2+}\right]_{\mathrm{i}}$ is a useful tool to determine the activation of these receptors. Using the $\mathrm{P}_{2} \mathrm{X}_{7}$ receptor agonist BzATP, we determined whether these receptors are functional in rat lacrimal gland. Lacrimal gland acini were isolated and incubated with the calcium indicator dye fura 2. It is well established that $\mathrm{P}_{2} \mathrm{X}_{7}$ receptor activity is enhanced in the absence of $\mathrm{Mg}^{2+}$; therefore, we performed experiments in the presence and absence of $\mathrm{Mg}^{2+}$. Under these experimental conditions, $\mathrm{MgSO}_{4}$ was omitted from the standard KRB buffer. In the presence of $\mathrm{Mg}^{2+}$, BzATP $\left(10^{-6}\right.$ M) did not increase $\left[\mathrm{Ca}^{2+}\right]_{\mathrm{i}}$, and none of the acini in the field responded (Fig. 3A). BzATP $10^{-5} \mathrm{M}$ increased $\left[\mathrm{Ca}^{2+}\right]_{\mathrm{i}}$ a small amount despite the fact that $100 \%$ of the cells in the field responded (Figs. 3A, 3B). BzATP $10^{-4} \mathrm{M}$ increased $\left[\mathrm{Ca}^{2+}\right]_{\mathrm{i}}$ more substantially (Fig. 3A) with all acini responding. In the absence of $\mathrm{Mg}^{2+}$, BzATP $10^{-6}, 10^{-5}$, and $10^{-4} \mathrm{M}$ increased $\left[\mathrm{Ca}^{2+}\right]_{\mathrm{i}}$ in a time-dependent manner (Figs. 3C, 3D) with $86 \%, 100 \%$, and $92 \%$ of acini responding, respectively.

Figure 3E represents the change in peak calcium concentration over basal at each concentration of BzATP in the presence and absence of $\mathrm{Mg}^{2+}$. In the absence of $\mathrm{Mg}^{2+}$, the peak calcium concentration with BzATP $10^{-6} \mathrm{M}$ was $33 \pm 3 \mathrm{nM}$, which was significantly increased above the peak calcium concentration of $5 \pm 3 \mathrm{nM}$ in the presence of $\mathrm{Mg}^{2+}$. Similarly, the peak calcium concentration was $155 \pm 32$ at BzATP $10^{-5}$ in the absence of $\mathrm{Mg}^{2+}$. This was significantly increased above the value in the presence of $\mathrm{Mg}^{2+}$ of $43 \pm 23$. BzATP $10^{-4} \mathrm{M}$ in the absence of $\mathrm{Mg}^{2+}$ was increased to $168 \pm 42 \mathrm{nM}$, though not significantly, from $80 \pm 32$ in the presence of $\mathrm{Mg}^{2+}$. These experiments demonstrate that $\mathrm{P} 2 \mathrm{X}_{7}$ receptors are activated by BzATP in rat lacrimal gland.

\section{Effect of Inhibition of $\mathrm{P} 2 \mathrm{X}_{\mathbf{7}}$ Receptors on $\left[\mathrm{Ca}^{2+}\right]_{\mathbf{i}}$}

To ensure that the increase in $\left[\mathrm{Ca}^{2+}\right]_{\mathrm{i}}$ seen with BzATP was due to activation of the $\mathrm{P} 2 \mathrm{X}_{7}$ receptor, acini were incubated with fura 2 , as described previously, and $\mathrm{P} 2 \mathrm{X}_{7}$ antagonists were added for the last 20 minutes of fura 2 incubation. The first antagonist used was Brilliant Blue $\mathrm{G}(\mathrm{BBG})$, which is a selective inhibitor for $\mathrm{P} 2 \mathrm{X}_{7}$ receptors. After preincubation with BBG $\left(10^{-6}\right.$ and $\left.10^{-5} \mathrm{M}\right)$, the cells were then stimulated with BzATP $10^{-5} \mathrm{M}^{\text {in }} \mathrm{Mg}^{2+}$-free buffer, and $\left[\mathrm{Ca}^{2+}\right]_{\mathrm{i}}$ was measured. The $\mathrm{Ca}^{2+}$ trace of the mean of three experiments is shown in Figure $4 \mathrm{~A}$, indicating that BBG $10^{-6} \mathrm{M}$ partially inhibited $\left[\mathrm{Ca}^{2+}\right]_{\mathrm{i}}$ stimulated by BzATP $10^{-5} \mathrm{M}$, whereas BBG $10^{-5} \mathrm{M}$ completely inhibited this response. When three independent experiments were analyzed for peak $\left[\mathrm{Ca}^{2+}\right]_{\mathrm{i}}$, BzATP $10^{-5} \mathrm{M}$ increased $\left[\mathrm{Ca}^{2+}\right]_{\mathrm{i}}$ to $123 \pm 36 \mathrm{nM}$. This response was inhibited by $55 \pm 20 \%$ to $55 \pm 22 \mathrm{nM}$ by BBG $10^{-6} \mathrm{M}$ and $91 \pm 2 \%$ to $9 \pm 1 \mathrm{nM}$ by BBG $10^{-5} \mathrm{M}$ (Fig. 4B).

To confirm the results obtained with $\mathrm{BBG}$, we used a second inhibitor of $\mathrm{P} 2 \mathrm{X}_{7}$ receptors, A 438079 , which is a highly selective competitive inhibitor of the $\mathrm{P} 2 \mathrm{X}_{7}$ receptor that does not react with other P2 receptors. In $\mathrm{Mg}^{2+}$-free buffer, A $438079\left(10^{-7}-10^{-4} \mathrm{M}\right)$ inhibited BzATPstimulated $\left[\mathrm{Ca}^{2+}\right]_{\mathrm{i}}$ in a concentration-dependent manner, with A $43807910^{-4} \mathrm{M}$ causing complete inhibition of this response (Fig. 4C). The peak increase in $\left[\mathrm{Ca}^{2+}\right]_{\mathrm{i}}$ stimulated by BzATP $10^{-5} \mathrm{M}$ in the absence of $\mathrm{Mg}^{2+}$ was $95 \pm 22 \mathrm{nM}$, which was inhibited by $25 \pm 10,46$ $\pm 23,80 \pm 10$, and $88 \pm 8 \%$ to $77 \pm 24,66 \pm 38,19 \pm 12$, and $13 \pm 10 \mathrm{nM}$ at $10^{-7}, 10^{-6}, 10^{-5}$, and $10^{-4} \mathrm{M}$ A 438079 , respectively. To ensure that A $438079\left(10^{-5} \mathrm{M}\right)$, which completely inhibited the BzATP response, was not toxic to the acini, $\operatorname{Cch}\left(10^{-4} \mathrm{M}\right)$, an agonist known to increase $\left[\mathrm{Ca}^{2+}\right]_{\mathrm{i}}$ in the lacrimal gland, was added after BzATP. As shown in Figure $4 \mathrm{C}, \mathrm{Cch}$ increased $\left[\mathrm{Ca}^{2+}\right]_{\mathrm{i}}$ to $225 \mathrm{nM}$ despite the fact that the cells did not respond to BzATP. Both inhibitors block BzATP-stimulated $\left[\mathrm{Ca}^{2+}\right]_{\mathrm{i}}$, indicating that BzATP activates the $\mathrm{P} 2 \mathrm{X}_{7}$ receptor in the lacrimal gland to increase $\left[\mathrm{Ca}^{2+}\right]_{\mathrm{i}}$. 


\section{Effect of Activation of $\mathrm{P}_{2} \mathrm{X}_{\mathbf{7}}$ Receptors on Protein Secretion}

Because the lacrimal gland secretes the majority of the aqueous portion of the tear film, we determined the effect of activation of the $\mathrm{P} 2 \mathrm{X}_{7}$ receptor on lacrimal gland protein secretion. Acini were isolated and incubated with the $\mathrm{P} 2 \mathrm{X}_{7}$ receptor-specific agonist BzATP $10^{-5}$ and $10^{-4} \mathrm{M}$ in the presence or absence of $\mathrm{Mg}^{2+}$. BzATP in the presence of $\mathrm{Mg}^{2+}$ significantly increased protein secretion to $1.2 \pm 0.06$ - and $1.2 \pm 0.05$-fold times basal at $10^{-5}$ and $10^{-4} \mathrm{M}$, respectively (Fig. 5A). This is in comparison to the response of $1.4 \pm 0.1$-fold times basal seen in the presence of the cholinergic agonist $\mathrm{Cch}\left(10^{-4} \mathrm{M}\right)$, a well-known stimulus of lacrimal gland protein secretion. In the absence of $\mathrm{Mg}^{2+}$, protein secretion did not change with the addition of BzATP $10^{-5} \mathrm{M}$ but was significantly increased at BzATP $10^{-4} \mathrm{M}$ to $1.2 \pm 0.07$ fold times basal (Fig. 5B). There was also no difference between the basal values of protein secretion in the presence or absence of $\mathrm{Mg}^{2+}\left(13.1 \% \pm 6 \%\right.$ in the presence of $\mathrm{Mg}^{2+}$ and $13.7 \%$ $\pm 6 \%$ in the absence of $\mathrm{Mg}^{2+}$; data not shown). These experiments demonstrate that activation of $\mathrm{P} 2 \mathrm{X}_{7}$ receptors stimulates protein secretion.

\section{Effect of Inhibition of $\mathrm{P}_{2} \mathrm{X}_{\mathbf{7}}$ Receptors on BzATP-Stimulated Protein Secretion}

To ensure that peroxidase secretion stimulated with BzATP was also $\mathrm{P}_{2} \mathrm{X}_{7}$ receptor mediated, the acini were preincubated for 15 minutes with BBG $\left(10^{-7}-10^{-5} \mathrm{M}\right)$ before the addition of $\operatorname{BzATP}\left(10^{-4} \mathrm{M}\right)$ for 40 minutes in the absence of $\mathrm{Mg}^{2+}$. Peroxidase secretion was then measured. BzATP significantly increased secretion to $1.2 \pm 0.06$-fold times basal. As shown in Figure 6, BBG inhibited BzATP-stimulated secretion in a concentration-dependent manner, similar to the effects seen on $\left[\mathrm{Ca}^{2+}\right]_{\mathrm{i}}$. Secretion was inhibited $36 \% \pm 30 \%$ at BBG $10^{-7} \mathrm{M}$ to $1.16 \pm 0.06$ and significantly inhibited $59 \% \pm 10 \%$ and $86 \% \pm 6 \%$ to $1.1 \pm 0.01$-fold and 1.0 \pm 0.02 -fold times basal at BBG $10^{-6}$ and $10^{-5} \mathrm{M}$, respectively. These data indicate that BzATP is activating the $\mathrm{P} 2 \mathrm{X}_{7}$ purinergic receptor to stimulate protein secretion.

\section{Effect of P2X 7 Receptors on Activation of ERK 1/2}

We previously showed that ERK 1/2 (also known as p42/p44 MAPK) was activated by muscarinic, $\alpha_{1 D^{-a d r e n e r g i c, ~ a n d ~ E G F ~ r e c e p t o r s ~ i n ~ t h e ~ l a c r i m a l ~ g l a n d . ~}}{ }^{5,6,15}$ This activation attenuates agonist-stimulated protein secretion. Because $\mathrm{P} 2 \mathrm{X}_{7}$ receptors stimulate protein secretion, we investigated the effects of $\mathrm{P} 2 \mathrm{X}_{7}$ receptors on lacrimal gland ERK 1/2 activation. Acini were incubated with BzATP $\left(10^{-5}\right.$ and $\left.10^{-4} \mathrm{M}\right)$ or the cholinergic agonist $\mathrm{Cch}\left(10^{-4} \mathrm{M}\right)$ for 10 minutes either in the presence or absence of extracellular $\mathrm{Mg}^{2+}$. The amount of phosphorylated ERK 1/2 was then determined. In the presence of $\mathrm{Mg}^{2+}$, BzATP $\left(10^{-4}\right.$ and $10^{-5} \mathrm{M}$ ) did not activate ERK 1/2 at either concentration (Figs. 7A, 7B). These cells were responsive as $\mathrm{Cch}$ increased ERK 1/2 phosphorylation by 1.7 -fold times basal. In the absence of $\mathrm{Mg}^{2+}$, the amount of phosphorylated ERK $1 / 2$ was increased by $2.3 \pm 0.7$-fold times basal at BzATP $\left(10^{-5} \mathrm{M}\right)$ and was significantly increased by $2.7 \pm 0.5$-fold times basal at $10^{-4} \mathrm{M}$ (Figs. 7C, 7D)

Acini were preincubated with BBG $\left(10^{-7}-10^{-5}\right) \mathrm{M}$ for 20 minutes before stimulation with $\operatorname{BzATP}\left(10^{-4} \mathrm{M}\right)$ for 10 minutes in $\mathrm{Mg}^{2+}$-free KRB-HEPES buffer. The amount of phosphorylated ERK 1/2 was then determined. BzATP significantly increased the phosphorylated ERK $1 / 2$ by $1.3 \pm 0.05$-fold times basal. This increase was significantly inhibited by $69 \% \pm 23 \%, 67 \% \pm 23 \%$, and $100 \% \pm 0 \%$ to $1.1 \pm 0.3$-fold, $1.0 \pm 0.2$-fold, and $0.9 \pm 0.3$-fold times basal by BBG at $10^{-7}, 10^{-6}$, and $10^{-5} \mathrm{M}$, respectively (Fig. 8).

\section{DISCUSSION}

In the present study, we demonstrate that $\mathrm{P} 2 \mathrm{X}_{7}$ purinergic receptors are present and functional in the lacrimal gland. $\mathrm{P} 2 \mathrm{X}_{7}$ receptors were detected by both immunofluorescence and Western blot analysis. The receptors were functional $\mathrm{P} 2 \mathrm{X}_{7}$ receptors because BzATP-induced $\mathrm{Ca}^{2+}$ 
response was increased in the absence of extracellular $\mathrm{Mg}^{2+}$ and inhibited by two specific antagonists, BBG and A 438079. Activation of $\mathrm{P}_{2} \mathrm{X}_{7}$ receptors not only increased intracellular $\mathrm{Ca}^{2+}$ but stimulated protein secretion and ERK activity. Thus the lacrimal gland contains typical $\mathrm{P} 2 \mathrm{X}_{7}$ receptors.

$\mathrm{P} 2 \mathrm{X}_{7}$ purinergic receptors have been identified in salivary glands ${ }^{16}$ and implicated in their secretion from salivary glands. ${ }^{17}$ Interestingly, ATP was shown to inhibit cholinergic-agonist induced secretion, which did not occur in salivary glands from $\mathrm{P} 2 \mathrm{X}_{7}$ knockout mice. ${ }^{17}$ This implies that ATP modulates the response of salivary glands. Because cholinergic agonists are major stimuli of lacrimal gland protein secretion, it would be of interest to determine whether activation of $\mathrm{P} 2 \mathrm{X}_{7}$ purinergic receptors has similar effects.

It is well established that the effects of $\mathrm{P} 2 \mathrm{X}_{7}$ purinergic receptors are intensified in the absence of extracellular $\mathrm{Mg}^{2+} .{ }^{18}$ This was demonstrated in the lacrimal gland when removal of $\mathrm{Mg}^{2+}$ from the buffer increased the rise in $\left[\mathrm{Ca}^{2+}\right]_{\mathrm{i}}$ stimulated by BzATP. However, removal of $\mathrm{Mg}^{2+}$ from the buffer did not increase the amount of peroxidase secretion, and, in fact, secretion was unchanged between the two conditions. The fusion of secretory granules and the release of their components into the lumen is the end point of a series of complicated processes. In contrast, the rise in $\left[\mathrm{Ca}^{2+}\right]_{\mathrm{i}}$ because of the activation of $\mathrm{P} 2 \mathrm{X}_{7}$ receptors occurs soon after activation of the receptor. It is possible that $\mathrm{Mg}^{2+}$ is essential for a step occurring distal to the increase in $\left[\mathrm{Ca}^{2+}\right]_{\mathrm{i}}$ and before exocytosis. In support of this, it is known that several mechanisms leading to exocytosis involve ATP hydrolysis, which is dependent on $\mathrm{Mg}^{2+}$. In the lacrimal gland, these mechanisms include actin reorganization at the apical membrane and association with nonmuscle myosin II, ${ }^{19}$ which occurs on cholinergic agonist stimulation.

The interesting $\mathrm{Ca}^{2+}$ response in the presence of BzATP $10^{-5} \mathrm{M}$ (Fig. 3C) occurred often, though not every time ( 6 of 9 rats). This occurred in the three experiments shown in Figure 3A and the three experiments shown in Figure 4A, but not in the three experiments shown in Figure $4 \mathrm{C}$. We have observed that there is heterogeneity in the $\left[\mathrm{Ca}^{2+}\right]_{\mathrm{i}}$ response in that though all acini respond to BzATP, they do so at different rates. Some acini respond immediately to the stimulus, but other acini respond at a later time. We do not see this at higher concentrations of BzATP. Li et al. ${ }^{20}$ demonstrated similar changes in $\left[\mathrm{Ca}^{2+}\right]_{\mathrm{i}}$ in response to BzATP in human cervical cells. They established that the initial $\mathrm{Ca}^{2+}$ peak was attributed to the opening of the pores on the apical membranes and that the delayed response was attributed to the opening of the pores in the basolateral membranes. Because $\mathrm{P} 2 \mathrm{X}_{7}$ receptors are also present on apical and basolateral membranes of acinar and duct cells, this could also occur in the lacrimal gland.

In the lacrimal gland, it is not known from where the ATP originates to stimulate $\mathrm{P}_{2} \mathrm{X}_{7}$ purinergic receptors. ATP can be released together with neurotransmitters from nerves, ${ }^{21}$ constitutively from many cells types, or as a result of a variety of stimuli, including mechanical stimuli, cell swelling, and inflammatory stimuli. ${ }^{22-24}$ In the lacrimal gland, there are three major cell types, acinar, ductal, and myoepithelial cells. Under normal conditions, stimuli from the external environment can activate the parasympathetic and sympathetic nerves in the lacrimal gland to release their neurotransmitters. This activation can cause the rapid, shortterm release of ATP from sympathetic nerve terminals, myoepithelial cells in response to cholinergic agonist-induced contraction, or acinar cells in response to activation of muscarinic or $\alpha_{1 \mathrm{D}}$ adrenergic receptors. The released ATP can then act in either an autocrine or a paracrine manner, binding to the $\mathrm{P} 2 \mathrm{X}_{7}$ receptors located on lacrimal gland cells.

It is possible that with the inflammation that develops with aging and in the disease progression of Sjögren syndrome, there is a prolonged presence of ATP either from an increase in the release from the lymphocytes that infiltrate the gland, a decrease in the extracellular enzymes that break down ATP, or a decrease in the adenosine P1 receptors that can be protective. The 
ATP could cause a prolonged activation of the $\mathrm{P} 2 \mathrm{X}_{7}$ receptors to induce pore formation to cause acinar cell death. Thus the lacrimal gland could be a target of inflammation-induced activation of $\mathrm{P} 2 \mathrm{X}_{7}$ receptors leading to disease pathogenesis, as has already been proposed for diabetes, lupus, and Alzheimer's disease. ${ }^{25-27}$

In this study, we have focused exclusively on the $\mathrm{P} 2 \mathrm{X}_{7}$ purinergic receptors. ATP can be converted to ADP, AMP, and adenosine, all which bind to other types of purinergic receptors. It is known that $\mathrm{P} 1$ receptors are present in the rabbit lacrimal gland, ${ }^{28}$ and preliminary evidence indicates that all the P2X receptors with the exception of the P2X5 receptor are present in the rat lacrimal gland. Thus purinergic receptors could play a significant role in the normal function of the lacrimal gland.

In conclusion, this study demonstrated that $\mathrm{P} 2 \mathrm{X}_{7}$ receptors are present in the lacrimal gland. These receptors are functional because activation leads to an increase in $\left[\mathrm{Ca}^{2+}\right]_{\mathrm{i}}$, protein secretion, and ERK 1/2 activation. These receptors may play a significant role in the lacrimal gland in health and disease.

\section{Acknowledgments}

Supported by National Institutes of Health Grant EY06177.

\section{References}

1. Hodges RR, Dartt DA. Regulatory pathways in lacrimal gland epithelium. Int Rev Cytol 2003;231:129_ 196. [PubMed: 14713005]

2. Dartt DA, Baker AK, Vaillant C, et al. Vasoactive intestinal polypeptide stimulation of protein secretion from rat lacrimal gland acini. Am J Physiol 1984;247(pt 1):G502-G509. [PubMed: 6093581]

3. Dartt DA, Dicker DM, Ronco LV, et al. Lacrimal gland inositol trisphosphate isomer and inositol tetrakisphosphate production. Am J Physiol 1990;259(pt 1):G274-G281. [PubMed: 2382726]

4. Hodges RR, Dicker DM, Rose PE, et al. Alpha 1-adrenergic and cholinergic agonists use separate signal transduction pathways in lacrimal gland. Am J Physiol 1992;262(pt 1):G1087-G1096. [PubMed: 1319686]

5. Hodges RR, Rios JD, Vrouvlianis J, et al. Roles of protein kinase C, $\mathrm{Ca}^{2+}$, Pyk2, and c-Src in agonist activation of rat lacrimal gland p42/p44 MAPK. Invest Ophthalmol Vis Sci 2006;47(8):3352-3359. [PubMed: 16877402]

6. Ota I, Zoukhri D, Hodges RR, et al. Alpha 1-adrenergic and cholinergic agonists activate MAPK by separate mechanisms to inhibit secretion in lacrimal gland. Am J Physiol Cell Physiol 2003;284 (1):C168-C178. [PubMed: 12388118]

7. Hodges RR, Shatos MA, Tarko RS, et al. Nitric oxide and cGMP mediate alpha1D-adrenergic receptorstimulated protein secretion and p42/p44 MAPK activation in rat lacrimal gland. Invest Ophthalmol Vis Sci 2005;46(8):2781-2789. [PubMed: 16043851]

8. Burnstock G. Purine and pyrimidine receptors. Cell Mol Life Sci 2007;64(12):1471-1483. [PubMed: 17375261]

9. Dubyak GR. Go it alone no more-P2X7 joins the society of heteromeric ATP-gated receptor channels. Mol Pharmacol 2007;72(6):1402-1405. [PubMed: 17895406]

10. Bianco F, Pravettoni E, Colombo A, et al. Astrocyte-derived ATP induces vesicle shedding and IL-1 $\beta$ release from microglia. J Immunol 2005;174(11):7268-7277. [PubMed: 15905573]

11. Surprenant A, Rassendren F, Kawashima E, et al. The cytolytic P2Z receptor for extracellular ATP identified as a P2X receptor (P2X7). Science 1996;272(5262):735-738. [PubMed: 8614837]

12. Donnelly-Roberts DL, Jarvis MF. Discovery of P2X7 receptor-selective antagonists offers new insights into $\mathrm{P} 2 \mathrm{X} 7$ receptor function and indicates a role in chronic pain states. Br J Pharmacol 2007;151(5):571-579. [PubMed: 17471177]

13. Shibuya I, Tanaka K, Hattori Y, et al. Evidence that multiple P2X purinoceptors are functionally expressed in rat supraoptic neurones. J Physiol 1999;514(pt 2):351-367. [PubMed: 9852319] 
14. Hodges RR, Horikawa Y, Rios JD, et al. Effect of protein kinase C and $\mathrm{Ca}(2+)$ on p42/p44 MAPK, Pyk2, and Src activation in rat conjunctival goblet cells. Exp Eye Res 2007;85(6):836-844. [PubMed: 17919561]

15. Tepavcevic V, Hodges RR, Zoukhri D, et al. Signal transduction pathways used by EGF to stimulate protein secretion in rat lacrimal gland. Invest Ophthalmol Vis Sci 2003;44(3):1075-1081. [PubMed: 12601032]

16. McMillian MK, Soltoff SP, Cantley LC, et al. Two distinct cytosolic calcium responses to extracellular ATP in rat parotid acinar cells. Br J Pharmacol 1993;108(2):453-461. [PubMed: 8448596]

17. Nakamoto T, Brown DA, Catalan MA, et al. Purinergic P2X7 receptors mediate ATP-induced saliva secretion by the mouse submandibular gland. J Biol Chem 2009;284(8):4815-4822. [PubMed: 19097994]

18. Michel AD, Chessell IP, Humphrey PP. Ionic effects on human recombinant P2X7 receptor function. Naunyn Schmiedebergs Arch Pharmacol 1999;359(2):102-109. [PubMed: 10048594]

19. Jerdeva GV, Wu K, Yarber FA, et al. Actin and non-muscle myosin II facilitate apical exocytosis of tear proteins in rabbit lacrimal acinar epithelial cells. J Cell Sci 2005;118(pt 20):4797-4812. [PubMed: 16219687]

20. Li X, Gorodeski GI. Apically sorted P2X7 receptors mediate purinergic-induced pore formation preferentially in apical domains of the plasma membrane. Nucleosides Nucleotides Nucleic Acids 2006;25(9-11):1045-1049. [PubMed: 17065062]

21. Richardson PJ, Brown SJ. ATP release from affinity-purified rat cholinergic nerve terminals. J Neurochem 1987;48(2):622-630. [PubMed: 2432187]

22. Fitz JG. Regulation of cellular ATP release. Trans Am Clin Climatol Assoc 2007;118:199-208. [PubMed: 18528503]

23. Wan J, Ristenpart WD, Stone HA. Dynamics of shear-induced ATP release from red blood cells. Proc Natl Acad Sci U S A 2008;105(43):16432-16437. [PubMed: 18922780]

24. Franco R, Panayiotidis MI, de la Paz LD. Autocrine signaling involved in cell volume regulation: the role of released transmitters and plasma membrane receptors. J Cell Physiol 2008;216(1):14-28. [PubMed: 18300263]

25. Elliott JI, Higgins CF. Major histocompatibility complex class I shedding and programmed cell death stimulated through the proinflammatory P2X7 receptor: a candidate susceptibility gene for NOD diabetes. Diabetes 2004;53(8):2012-2017. [PubMed: 15277380]

26. Taylor SR, Gonzalez-Begne M, Dewhurst S, et al. Sequential shrinkage and swelling underlie P2X7stimulated lymphocyte phosphatidylserine exposure and death. J Immunol 2008;180(1):300-308. [PubMed: 18097031]

27. Rampe D, Wang L, Ringheim GE. P2X7 receptor modulation of beta-amyloid- and LPS-induced cytokine secretion from human macrophages and microglia. J Neuroimmunol 2004;147(1-2):56-61. [PubMed: 14741428]

28. Edman MC, Andersson SV, Delbro D, et al. Functional expression of the adenosine A1 receptor in rabbit lacrimal gland. Exp Eye Res 2008;86(1):110-117. [PubMed: 17998138] 
A

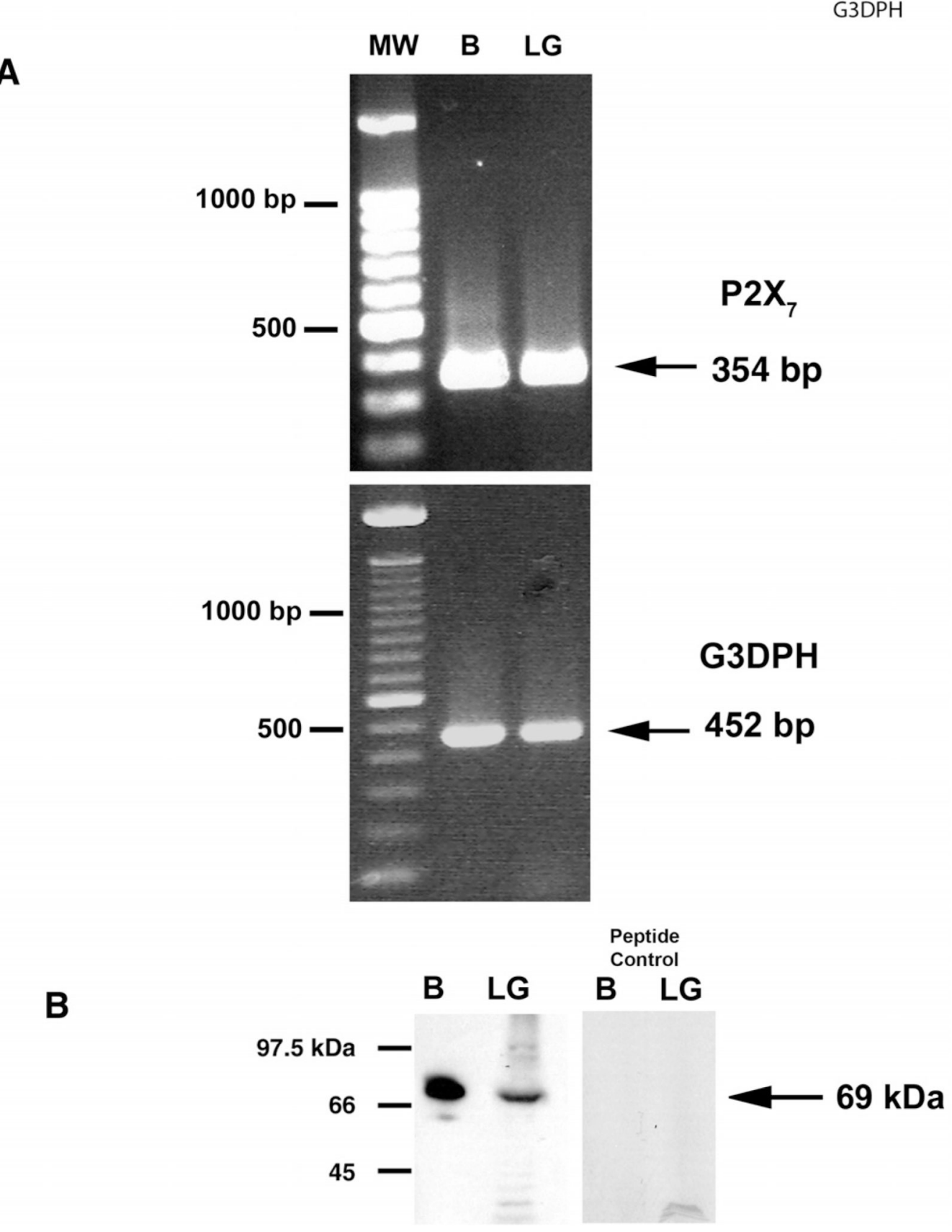

G3DPH

FIGURE 1.

Identification of $\mathrm{P}_{2} \mathrm{X}_{7}$ purinergic receptors in rat lacrimal gland. (A) RT-PCR was performed on total RNA isolated from rat brain (B) or lacrimal gland (LG) using primers specific to $\mathrm{P} 2 \mathrm{X}_{7}$ purinergic receptors and the housekeeping gene G3DPH. (B) Western blot analysis was performed on homogenate from rat brain (B) or lacrimal gland (LG) with a $\mathrm{P} 2 \mathrm{X}_{7}$ antibody and $\mathrm{P} 2 \mathrm{X}_{7}$ antibody preincubated with a control peptide. Blots are from a single animal and are representative of three separate animals. MW, molecular weight marker. 

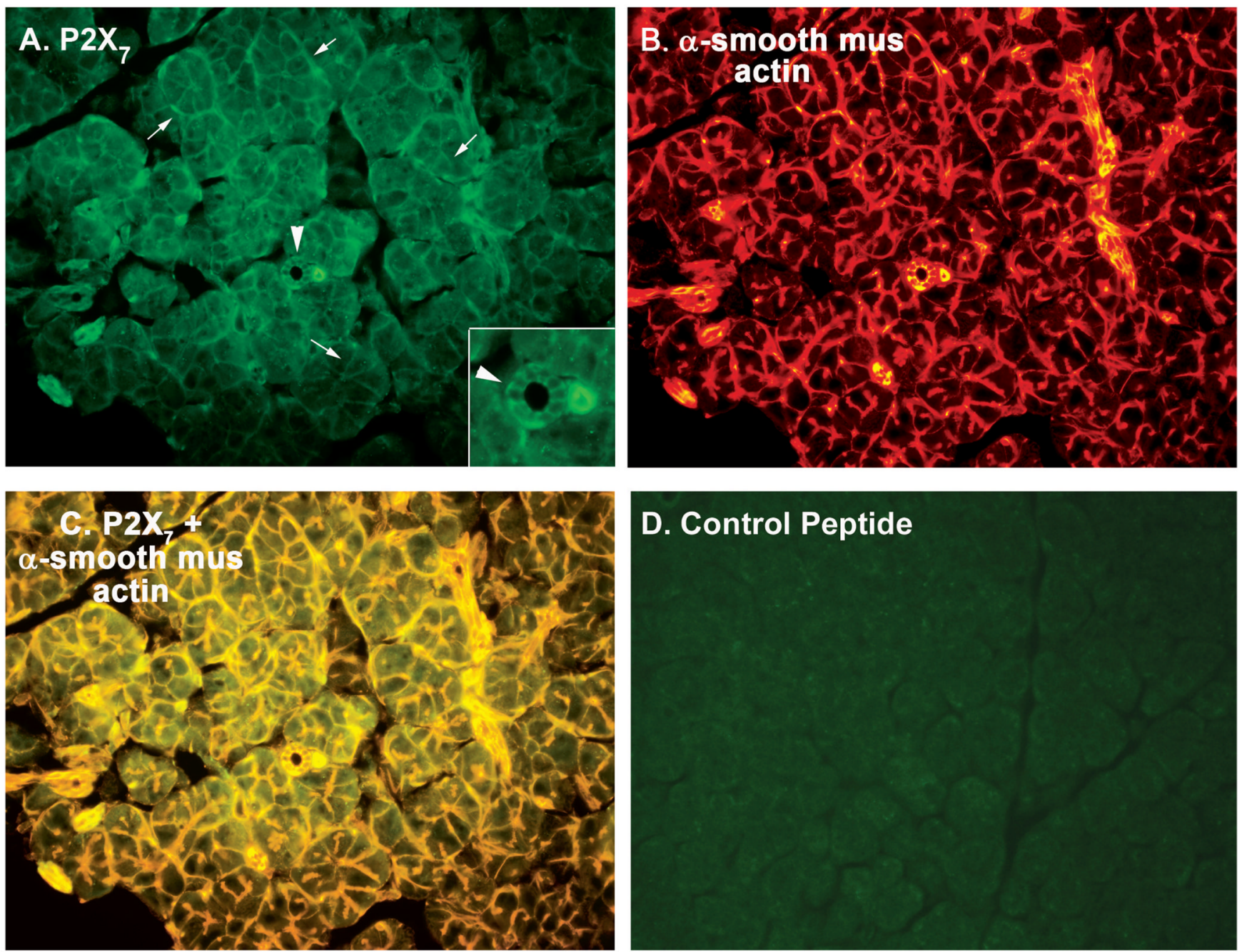

\section{Control Peptide}

FIGURE 2.

Localization of $\mathrm{P} 2 \mathrm{X}_{7}$ purinergic receptors in rat lacrimal gland. (A) Immunofluorescence micrographs showing the cellular distribution of $\mathrm{P}_{2} \mathrm{X}_{7}$ purinergic receptors. Arrows: basal and apical membranes of acinar cells. Arrowheads: basal membranes of ductal cells. Inset: $\mathrm{P}_{2} \mathrm{X}_{7}$ localization in ductal cells. (B) Phalloidin conjugated to rhodamine, which binds to actin. (C) Merged image of $\mathrm{P}_{2} \mathrm{X}_{7}$ purinergic receptors (green) and phalloidin (red). Yellow: overlap between the two proteins. (D) Lacrimal gland sections were incubated with $\mathrm{P}_{2} \mathrm{X}_{7}$ antibody and the control peptide. Micrographs are from a single animal and are representative of three individual animals. Original magnifications, $\times 200$; (inset) $\times 400$. 
A
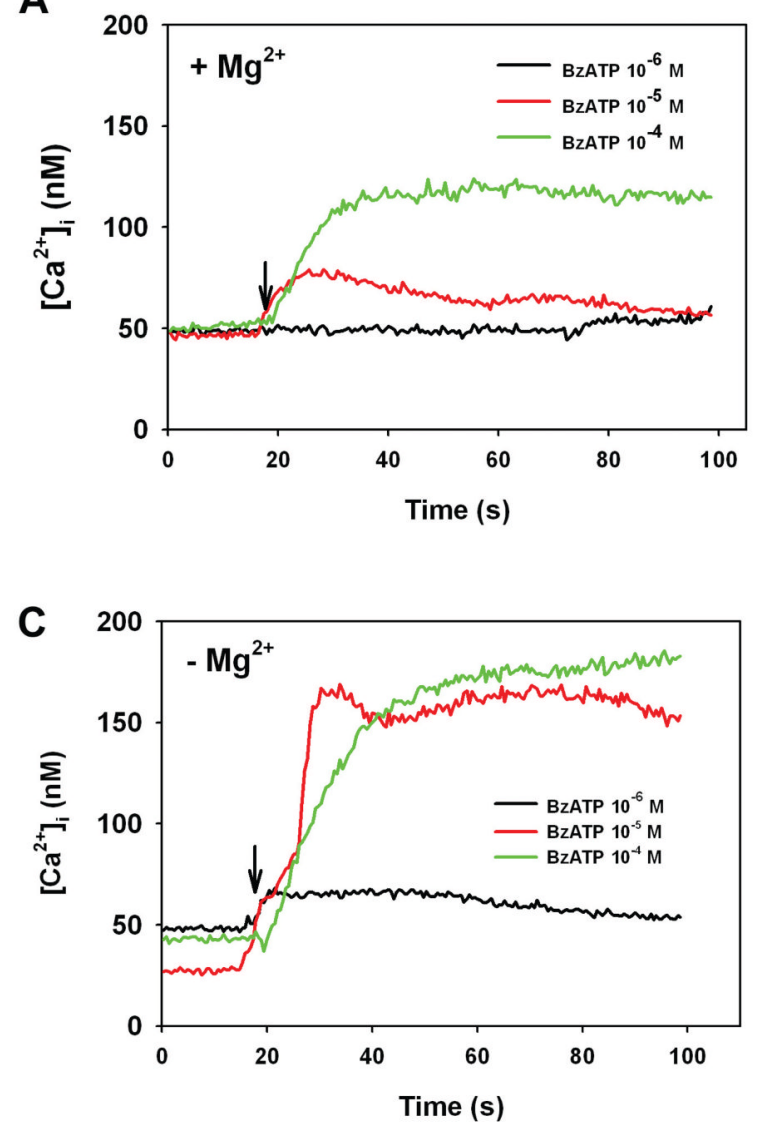

B

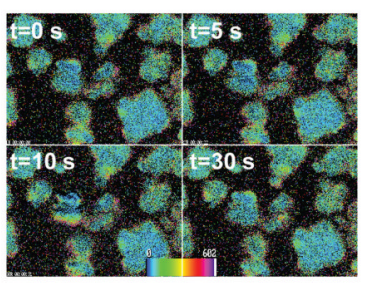

D

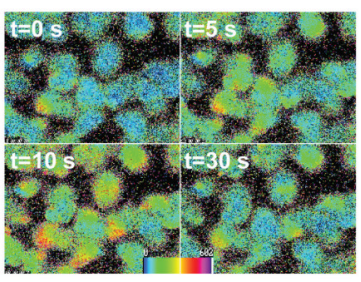

E

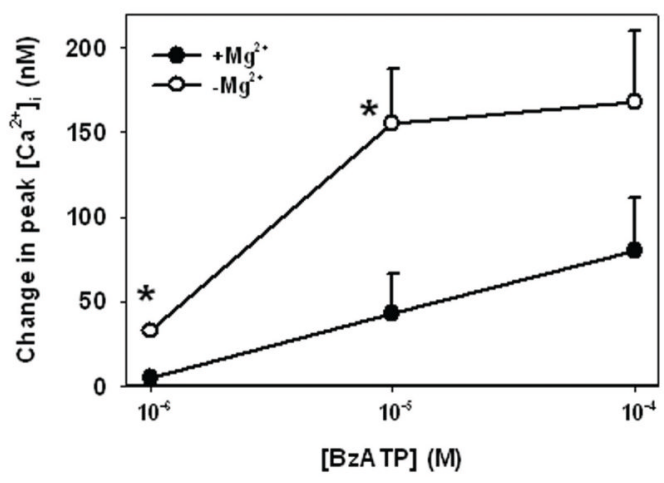

FIGURE 3.

Effect of activation of $\mathrm{P} 2 \mathrm{X}_{7}$ purinergic receptors on intracellular $\left[\mathrm{Ca}^{2+}\right]_{\mathrm{i}}$. Rat lacrimal gland acini were incubated with the calcium indicator molecule fura 2 before stimulation with varying concentrations of BzATP (A) in the presence of extracellular $\mathrm{Mg}^{2+}$ and $(\mathbf{C})$ in the absence of extracellular $\mathrm{Mg}^{2+}$. Arrows: addition of BzATP. Each trace is the average $\left[\mathrm{Ca}^{2+}\right]_{\mathrm{i}}$ values from three individual animals. Time-lapse fura-2 ratio images of acini stimulated with BzATP $\left(10^{-5} \mathrm{M}\right)$ in the presence $(\mathbf{B})$ and absence $(\mathbf{D})$ of $\mathrm{Mg}^{2+}$ are also shown. Times are after addition of BzATP. Pictures are representative of three individual animals. Color scale at bottom indicates $\left[\mathrm{Ca}^{2+}\right]_{\mathrm{i}}$. (E) Peak calcium values were calculated in the presence and absence of 
extracellular $\mathrm{Mg}^{2+}$. Values are mean $\pm \mathrm{SE}$ from three independent experiments. *Significant difference from values obtained in the presence of $\mathrm{Mg}^{2+}$ at each concentration. 

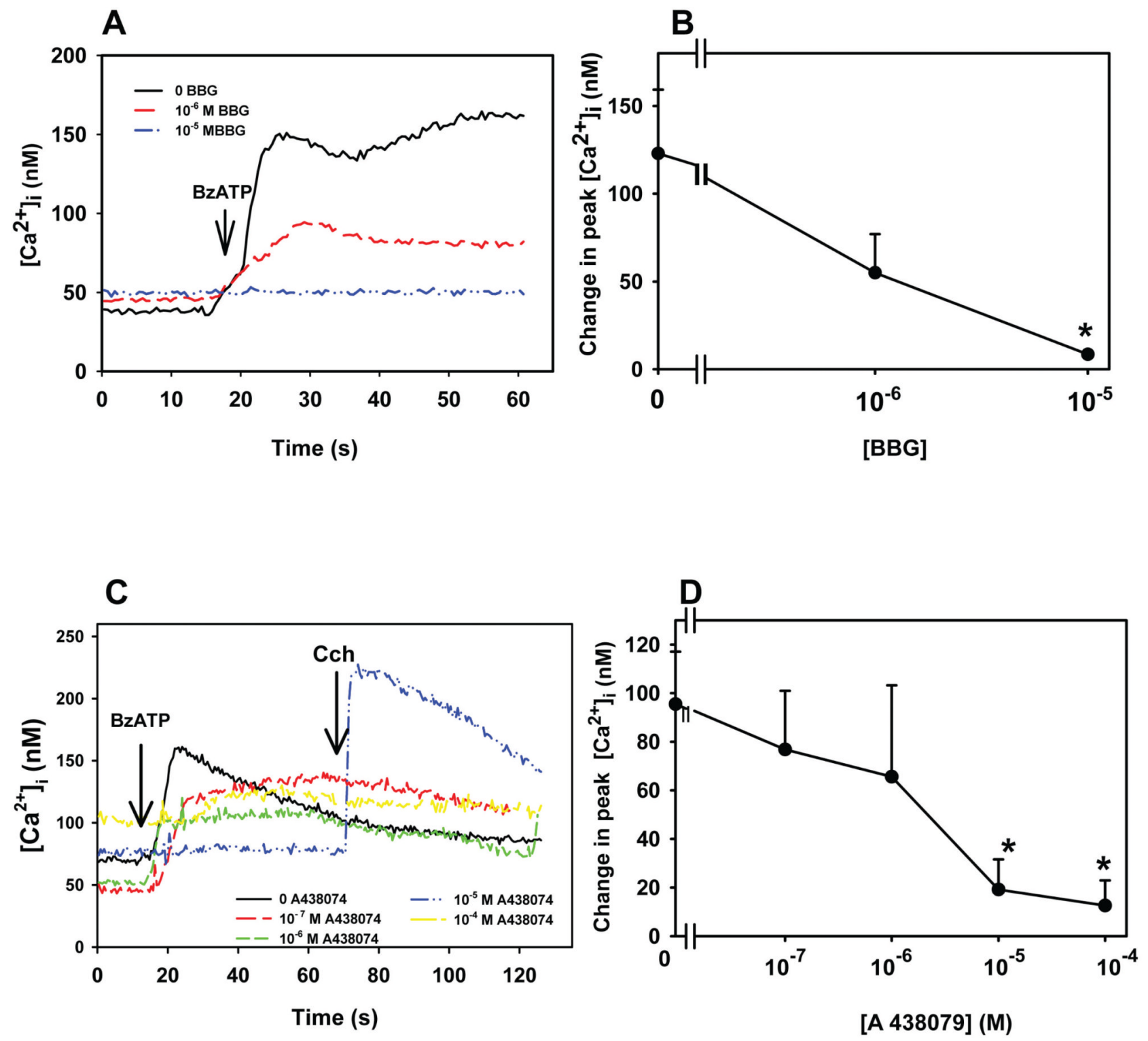

FIGURE 4.

Effect of inhibition of $\mathrm{P}_{2} \mathrm{X}_{7}$ purinergic receptors on BzATP-stimulated increase in $\left[\mathrm{Ca}^{2+}\right]_{\mathrm{i}}$. Rat lacrimal gland acini were incubated with the calcium indicator molecule fura 2 and increasing concentrations of $\mathrm{P}_{2} \mathrm{X}_{7}$ inhibitors BBG and A 438079 before stimulation with BzATP $\left(10^{-5}\right.$ $\mathrm{M})$ or the cholinergic agonist $\mathrm{Cch}\left(10^{-4} \mathrm{M}\right) . \mathrm{Ca}^{2+}$ traces of acini in the presence of either BBG (A) or A 438079 (C) are shown. Each trace is the average $\left[\mathrm{Ca}^{2+}\right]_{i}$ values from three individual animals. Peak calcium values were calculated in the presence and absence of BBG $(\mathbf{B})$ or A 438079 (D). Values are mean \pm SE from three independent experiments. *Significant difference from BzATP alone. 


\section{A}

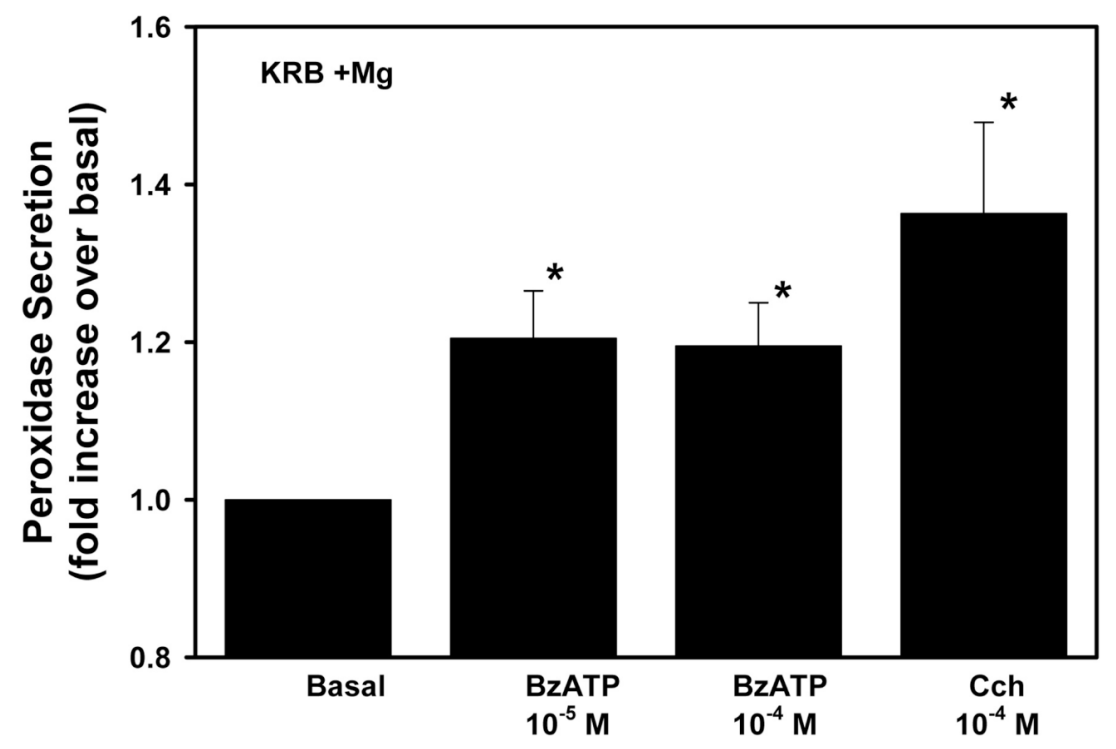

B

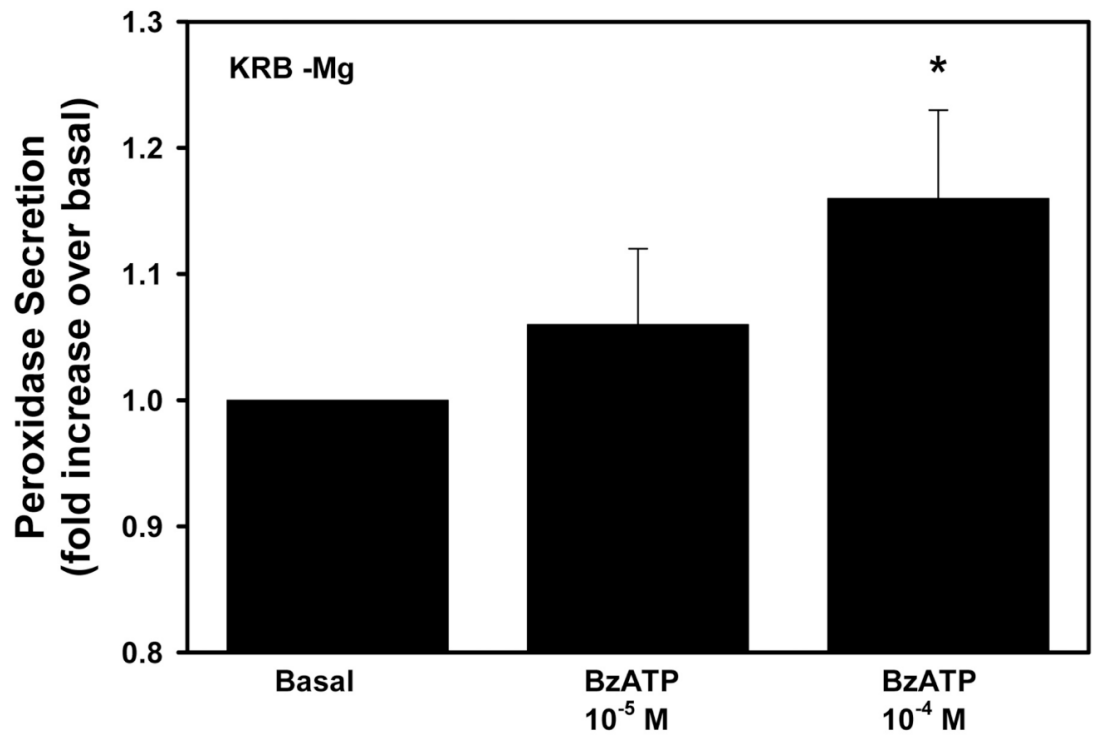

FIGURE 5.

Effect of activation of $\mathrm{P}_{2} \mathrm{X}_{7}$ purinergic receptors on protein secretion. Rat lacrimal gland acini were incubated with BzATP or Cch $\left(10^{-4} \mathrm{M}\right)$ for 40 minutes $(\mathbf{A})$ in the presence of extracellular $\mathrm{Mg}^{2+}$ and $(\mathbf{B})$ in the absence of extracellular $\mathrm{Mg}^{2+}$. Peroxidase was then measured. Values are mean \pm SE from three independent experiments. *Significant difference from basal alone. 


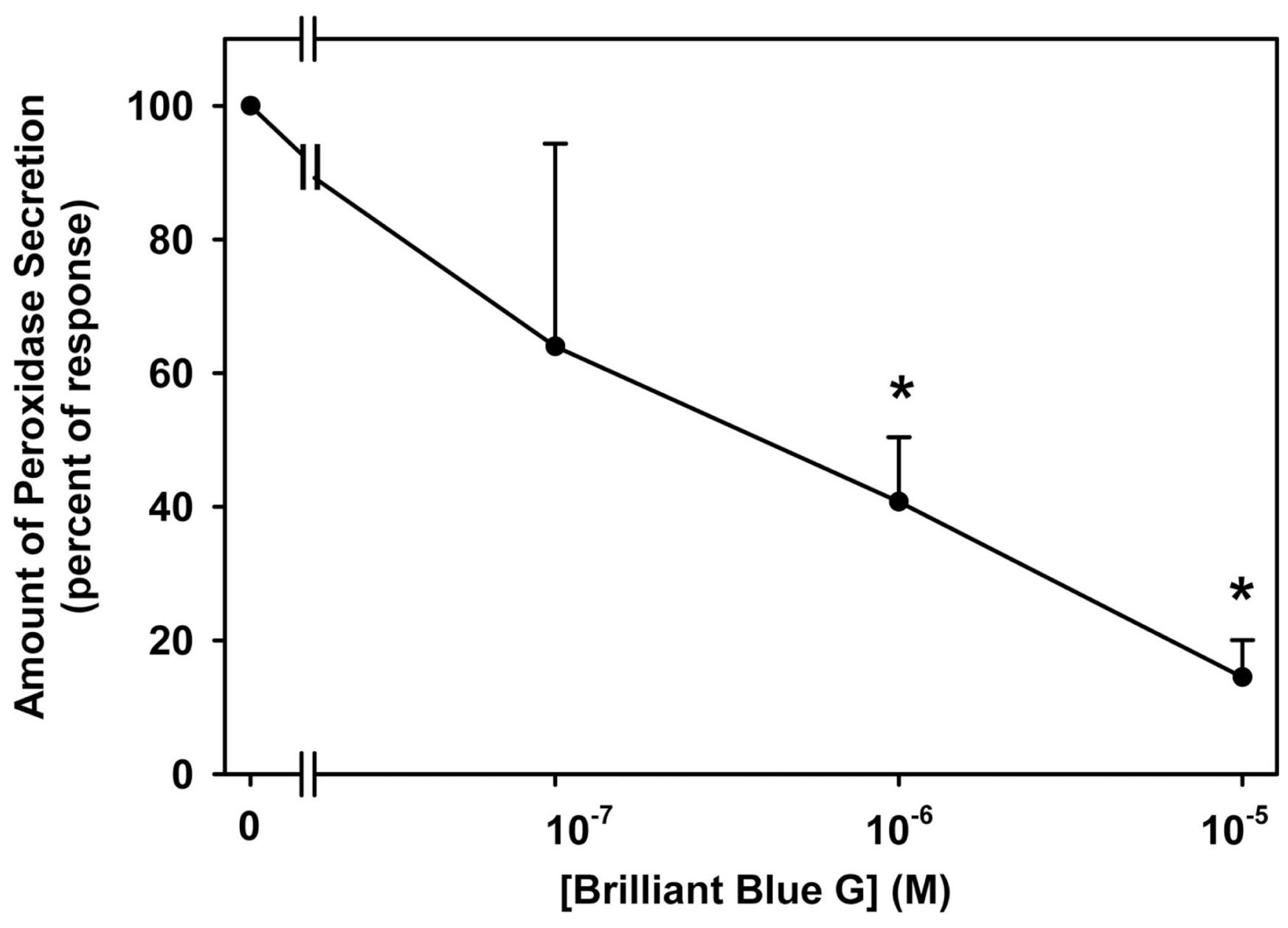

FIGURE 6.

Effect of inhibition of $\mathrm{P} 2 \mathrm{X}_{7}$ purinergic receptors on BzATP-stimulated protein secretion. Rat lacrimal gland acini were preincubated for 20 minutes with increasing concentrations of the $\mathrm{P} 2 \mathrm{X}_{7}$ inhibitor BBG before stimulation BzATP $\left(10^{-4} \mathrm{M}\right)$ for 40 minutes. Peroxidase was then measured, and percentage of response from BzATP alone was calculated. Values are mean \pm SE from four independent experiments. *Significant difference from BzATP alone. 

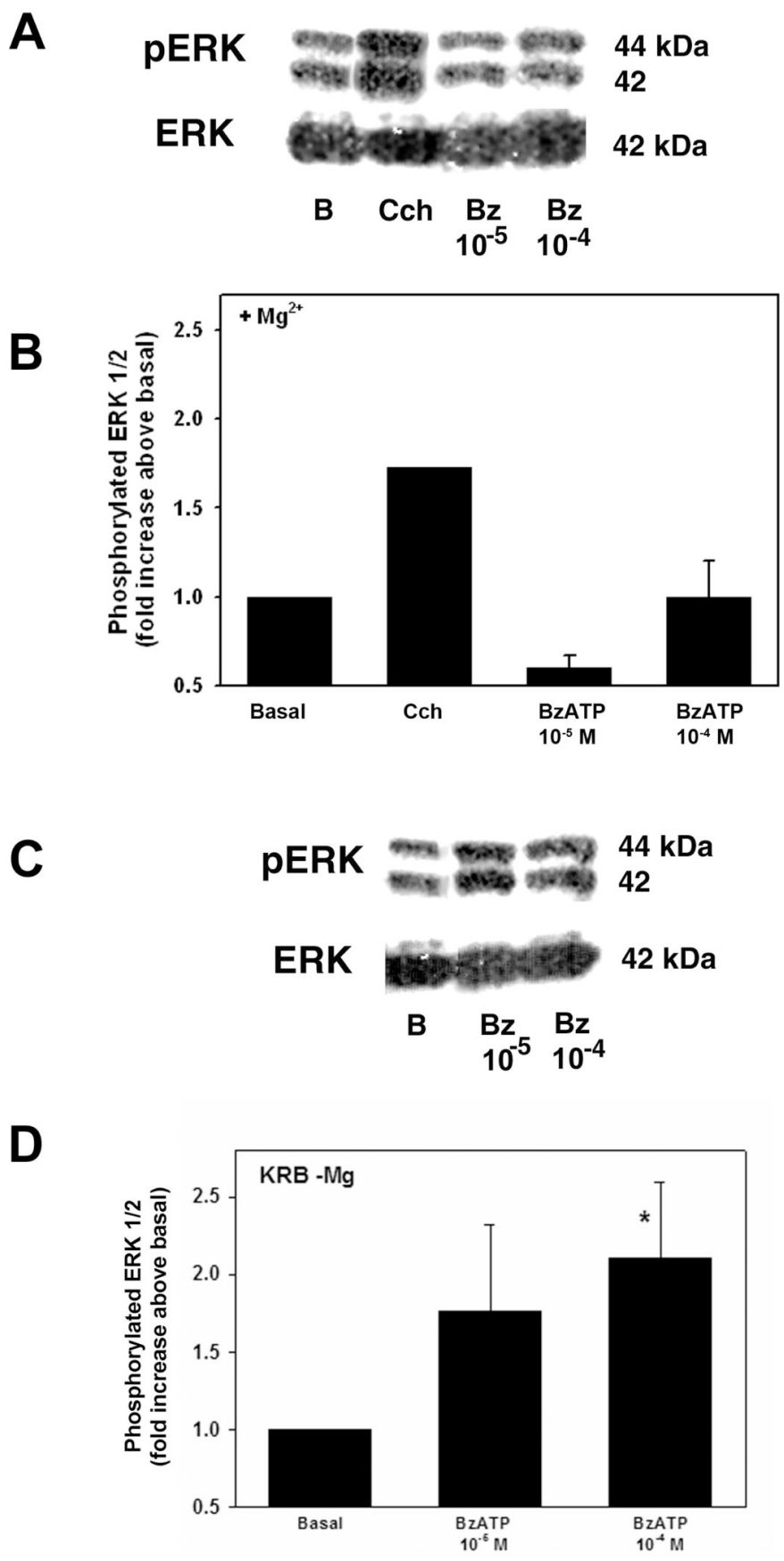

FIGURE 7.

Effect of Activation of $\mathrm{P}_{2} \mathrm{X}_{7}$ purinergic receptors on ERK 1/2 activation. Rat lacrimal gland acini were incubated with BzATP at the indicated concentrations in the presence $(\mathbf{A}, \mathbf{B})$ or absence $(\mathbf{C}, \mathbf{D})$ of extracellular $\mathrm{Mg}^{2+}$ for 10 minutes. Acini were homogenized, and proteins were analyzed by Western blot analysis, which was performed with antibodies against phosphorylated (activated) ERK 1/2 and total ERK 2. (A, C) Representative blots. (B, D) Values are mean \pm SE from four independent experiments for BzATP and 2 independent experiments for Cch. * Significant difference from basal $(\mathbf{B})$. 
A

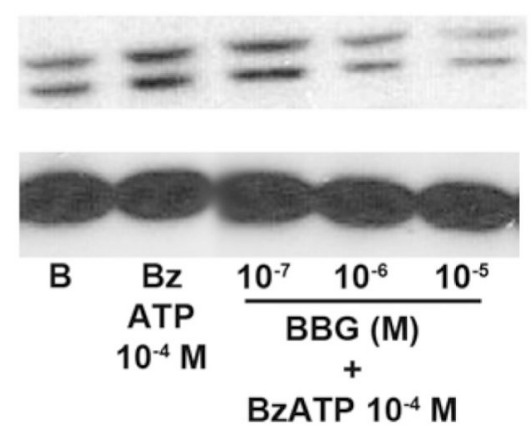

B

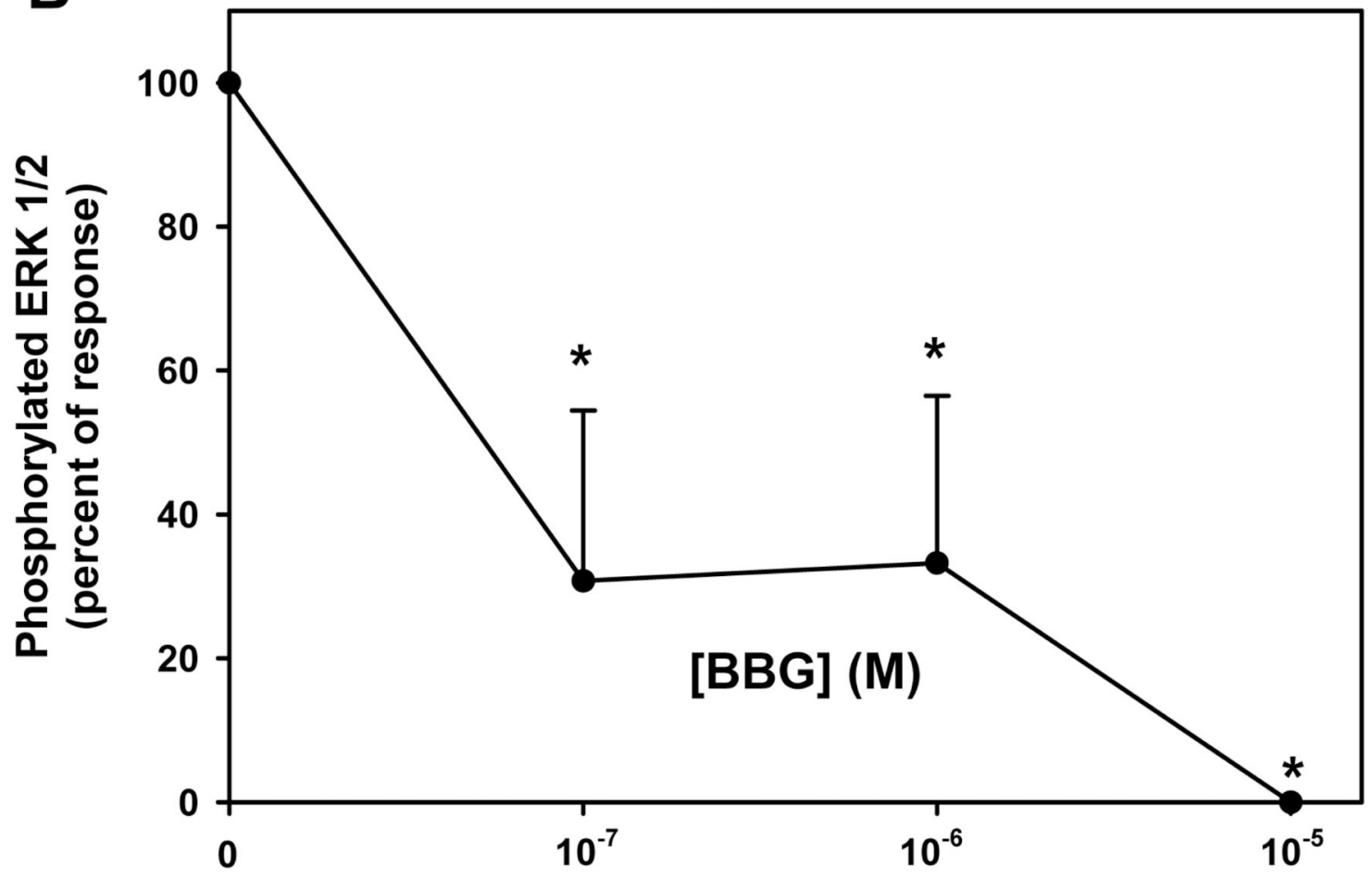

FIGURE 8.

Effect of inhibition of $\mathrm{P} 2 \mathrm{X}_{7}$ purinergic receptors on BzATP-stimulated ERK 1/2 activation. Rat lacrimal gland acini were preincubated with increasing concentrations of $\mathrm{P} 2 \mathrm{X}_{7}$ inhibitor BBG before stimulation. BzATP $\left(10^{-4} \mathrm{M}\right)$ in the absence of extracellular $\mathrm{Mg}^{2+}$ for 10 minutes. Acini were homogenized, and proteins were analyzed by Western blot analysis with antibodies against phosphorylated (activated) ERK 1/2 and total ERK 2. (A) Representative blot. (B) Percentage inhibition from BzATP alone was calculated. Values are mean $\pm \mathrm{SE}$ from four independent experiments. *Significant difference from BzATP alone. 